\title{
ВПЛИВ ЯКОСТІ ОЧИСТКИ МАСЛА НА МОТОРЕСУРС ДИЗЕЛЬНИХ ДВИГУНІВ АВТОМОБІЛЬНОГО ТРАНСПОРТУ
}

\author{
Марченко Д. Д., к. т. н., дои. \\ Миколаївський національний аграрний університет \\ DOI: https://doi.org/10.31435/rsglobal_ejits/30112018/6220
}

\section{ARTICLE INFO}

Received 11 September 2018 Accepted 27 November 2018 Published 30 November 2018

\section{ABSTRACT}

The methods of upgrading of motor oils which determine of engines exploited in different climatic terms and loading modes are described in the article.

\section{KEYWORDS}

motor oil,

engine,

different climatic terms

Citation: Марченко Д. Д. (2018) Vplyv Yakosti Ochystky Masla na Motoresurs Dyzelnykh Dvyhuniv Avtomobilnoho Transportu. European Journal of Intelligent Transportation Systems. 1(1). doi: 10.31435/rsglobal_ejits/30112018/6220

Copyright: (C) 2018 Марченко Д. Д. This is an open-access article distributed under the terms of the Creative Commons Attribution License (CC BY). The use, distribution or reproduction in other forums is permitted, provided the original author(s) or licensor are credited and that the original publication in this journal is cited, in accordance with accepted academic practice. No use, distribution or reproduction is permitted which does not comply with these terms.

В процесі експлуатації масел в них накопичуються продукти окислення, забруднення i інші домішки, які різко знижують якість масел. Масла, що містять забруднюючі домішки, нездатні задовольняти вимогам, що пред'являються до них, і повинні бути замінені свіжими маслами. Відпрацьовані масла збирають і піддають регенерації з метою збереження цінної сировини, що $є$ економічно вигідним.

Як виявлено виробничою експлуатацією тракторів, частина присадки, яка введена в масло, фільтрується відцентровими маслофільтрами двигуна, а також випадає в осад під час транспортування і зберігання. Це у свою чергу знижує експлуатаційні властивості масла, створюючи негативний вплив як на довговічність двигуна внутрішнього згоряє так і на час роботи самого масла.

Це в деякій мірі можливо компенсувати за рахунок додавання в масло присадок, які виготовляються як на органічних так і на металевій основі, що застосовувати в умовах експлуатації неможливо через невідомий їх склад.

Якість працюючого моторного масла можна покращити шляхом вдосконалення механізму очистки масла, наприклад, очистки його модернізованою центрифугою.

Для проведення експлуатаційних випробувань були вибрані 2 нових трактори МТ3-80. Кількість відпрацьованих мотогодин коливалася в межах 200-280 мотогодин.

Під час вибору тракторів для проведення експлуатаційних випробувань головну увагу надавалося їх технічному стану, і особливо, чад масла, витрата палива i проривання газів 3 сапуна двигуна. Для цього кожний трактор перевірявся по вище перерахованих показниках протягом двох робочих змін. Витрата палива перевіряли безпосередньо по показниках мірної лійки, чад масла відповідно долитого з мірного циліндра місткістю 0,5 л.; а кількість газів що проривалося з сапуна - за допомогою газового лічильника КИ-8940. 
Зіставлення результатів спостережень за тракторами дало підстави для можливості їх використовування для проведення експлуатаційних випробувань.

Перед початком проведення випробування всім тракторам було проведено 2-е технічне обслуговування згідно інструкції. При цьому піддон картера був знятий i ретельно промитий дизельним паливом. Після збірки двигуна заливалося свіже масло. При роботі двигуна контролювався тиск масла, яке було в допустимих межах. Точність роботи показника температури води перевірялося за допомогою ртутного термометра. Робота центрифуги перевірялася згідно інструкції після зупинки прогрітого двигуна. В головну масляну магістраль був вмонтований спеціальний штуцер для відбору проб масла в період випробування.

За весь період проведення експлуатаційних випробувань масло в картері двигуна не замінювали з огляду на те, що кількість відпрацьованих мотогодин не перевищувала 240-340 мотогодин.

Кількість відкладень в центрифузі визначали шляхом зважування ротора на терезах, через 60 мотогодин роботи двигуна; промивання центрифуги відбувалася через 120 годин роботи двигуна. Відбір проб масла в кількості 300 мл проводили кожні 60 мотогодин роботи двигуна. Доливу масла на компенсацію чаду проводили за допомогою мірних циліндрів місткістю 0,5 л з ціною розподілу 1 мл.

Отже при визначенні сорту масел для різних двигунів необхідно провести експлуатаційні випробування з подальшою оцінкою всіх фізико-хімічних показників масла і зносу деталей.

На рис. 1 приведені криві зміни концентрації механічних домішок в маслі для тракторів. 3 рисунка видно, що концентрація механічних домішок для масел з серійною центрифугою досить велика і складає після 240 годин роботи двигуна відповідно 2,4\%. Концентрація ж механічних домішок для масла з пропонуємою центрифугою низька $\mathrm{i}$ складає 1,69, що дещо нижче, ніж для масла з серійною центрифугою, тобто в 1,42 рази.

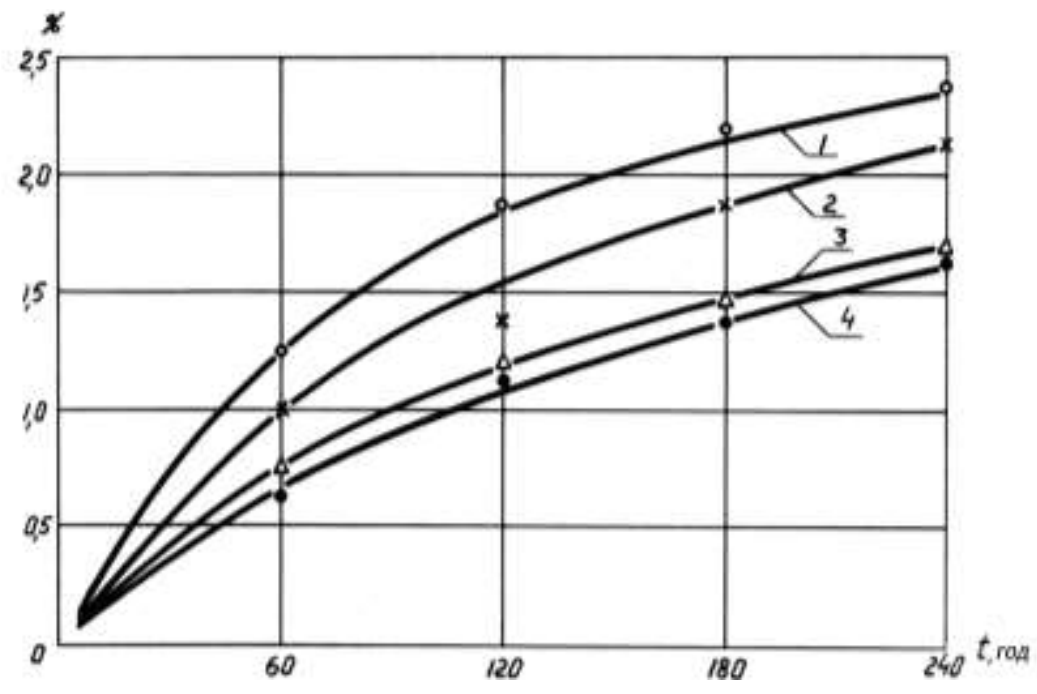

Рис. 1. Зміна змісту механічних домішок в маслі при експлуатаційних випробуваннях:

1, 2 - серійною иентрифугою, 3, 4- пропонуємою иентрифугою

Як видно з рис. 1, в перші 60 - 120 годин роботи двигуна в маслі відбувається інтенсивне накопичення механічних домішок. Надалі цей процес стабілізується.

Відомо, що з пониженням частоти обертання ротора центрифуги кількість механічних домішок зростає, на підставі чого зменшується ступінь очищення масла від домішок. При зростанні обертів центрифуги якість очищення масла зростає в порівнянні з серійною центрифугою, тому механічні домішки зменшуються за період 240 мотогод роботи двигуна 32,4 до 1,69 \%. 3 пониженням температури якість фільтрації масла значно погіршується. Ця обставина усугубляє ще і тим, що при холостому ходу або середніх оборотах двигуна тиск масла на вході в центрифугу значно зменшується, що сприяє ще більш гіршій фільтрації. 
Дослідженнями Г.О. Смірнова встановлено, що з пониженням температури масла 3 90 до $50^{\circ} \mathrm{C}$ коефіцієнт очищення масла знижується удвічі. Отже, якщо забезпечити температурний режим масла, що знаходиться в межах $80-85^{\circ} \mathrm{C}$ (близька до робочої в літніх умовах експлуатації), то можна понизити концентрацію нерозчинних продуктів в маслі удвічі. Враховуючи ту обставину, що обороти двигуна не постійні (отже, і тиск масла на вході в центрифугу змінюється); необхідно забезпечити таку конструкцію центрифуги, обороти якої б не змінювалися і були близькими до номінальних (10000 об/хв).

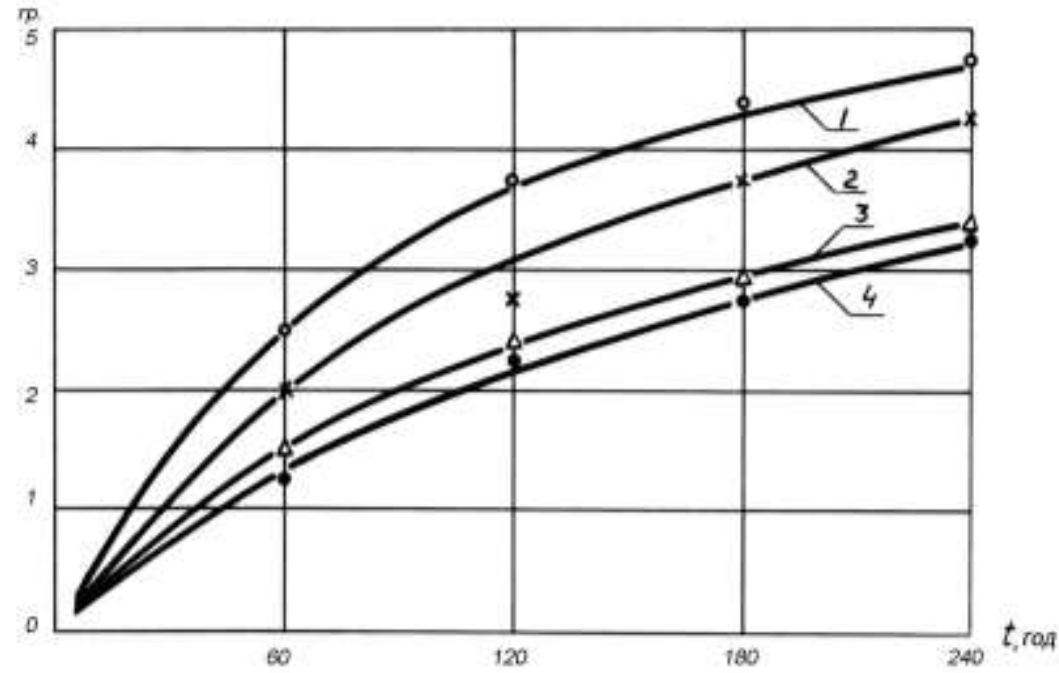

Рис. 2. Знос деталей двигунів тракторів при експлуатаціийних випробуваннях:

1,2 - серійними центтрифугами, 3, 4-пропонуємими центрифугами

Знос деталей двигуна, визначений методом спектрографії, виражений в гр. заліза, що знаходиться в маслі, відкладення з центрифуги, в пробах масла, а також в учаділому маслі представлений на рис. 2, до кінця випробувань має наступну тенденцію.

Відповідно для серійних центрифуг двигунів знос склав: 1 - 4,4 гр. При випробуваннях 3 пропонуємою центрифугою знос дорівнював 2,7 гр. Таким чином, мінімальний знос двигунів відбувається при роботі з пропонуємою центрифугою, який в 1,3 рази менше ніж з серійною центрифугою.

\section{ЛІТЕРАТУРА}

1. Кудрявцев Б. Б. Применение ультраакустических методов в практике физико-химических исследований / Кудрявцев Б. Б. - М., ГИТТЛ, 1952. 323 с. с ил.

2. Смирнов М. С. Влияние температуры охлаждающей жидкости и природы топлива на износ деталей цилиндро-поршневой группы дизелів / Смирнов М. С., Очеретяный И. Т. // Материалы II научнотехнического совещания по повышению износа деталей ЦПГ двигателей внутреннего сгорания, стр. 25, - М., 1968.

3. Арабян С. Г. Исследование и подбор картерных масел в соответствии с требованиями и условиями эксплуатации дизелів / Арабян С. Г. Кандидатская диссертация, М., 1959.

4. Павлов К. А. О замене масел в тракторных двигателях / Павлов К. А. // Техника в сельском хозяйстве №3, 1963, стр 82-86.

5. Венцель С. В. Смазка двигателей внутреннего сгорания / Венцель С. В. Машгиз, 1963, стр. 134.

6. Горобец П. 3. Эксплуатация тракторов в зимних условиях / Горобец П. 3. - М., Трудрезервиздат, 1975.

7. Синичкин М. А. Оценка эксплуатационных свойств масел при понижении температурных режимах работы двигателя / Синичкин М. А., Горобец В. И. // Химия и технология топлив и масел № 4, Изд-во Химия, 1964.

8. Заславский Ю. С. Методика стендовых испытаний масел на осадкообразование при низких рабочих температурах двигателя // Заславский Ю. С. - Гостоптехиздат, 1973.

9. Виппер А. Б. Моторные и реактивные масла и жидкости / Виппер А. Б. Изд. 4, Изд-во - Химия, М. 1963, стр.299.

10. Резников В.Д. Применение дизельных масел с присадками в форсированных двигателях / Резников В. Д. ЦНИИТЭ нефтехим, 1966, стр. 5. 